GEFAD / GUJGEF41(2): 631-659(2021)

\title{
Covid-19 Pandemi Sürecinde Uygulanan Uzaktan Eğitim Hakkında Ortaöğretim Öğrencilerinin Görüşlerinin Belirlenmesi*
}

\section{Determination of Secondary Education Students' Views on Distance Education Applied in the Covid-19 Pandemic Process}

\author{
Selçuk ARIK ${ }^{1}$, Ferhat KARAKAYA ${ }^{2}$, Osman ÇIMEN ${ }^{3}$, Mehmet YILMAZ $^{4}$ \\ ${ }^{1}$ Tokat Gaziosmanpaşa Üniversitesi, Eğitim Fakültesi, Fen Bilgisi Eğitimi Anabilim \\ Dal..selcuk.arik@gop.edu.tr \\ ${ }^{2}$ Yozgat Bozok Üniversitesi, Eğitim Fakültesi, Biyoloji Ĕ̆itimi Anabilim Dalı. \\ ferhatk26@gmail.com \\ ${ }^{3}$ Gazi Üniversitesi, Eğitim Fakültesi, Biyoloji Eğitimi Anabilim Dalı. \\ myilmaz@gazi.edu.tr \\ ${ }^{4}$ Gazi Üniversitesi, Eğitim Fakültesi, Biyoloji Eğitimi Anabilim Dalı. \\ osman.cimen@gmail.com
}

Makalenin Geliş Tarihi: 23.04.2021

Yayına Kabul Tarihi: 06.07.2021

\begin{abstract}
$\ddot{O} Z$
Bu araştırmada, COVID-19 pandemi sürecinde uygulanan uzaktan eğitim hakkında ortaöğretim ögrencilerinin görüşlerinin belirlenmesi amaçlanmıştır. Nitel araştırma yöntemlerinden durum çalışması desenine göre tasarlanan araştırmanın katılımcılarını Türkiye'nin farklı illerinde ögrenimine devam eden 55 ortaöğretim öğrencisi oluşturmuştur. Araştırmanın verileri araştırmacılar tarafindan hazırlanan "yarı yapılandırılmış görüşme formu” aracılı̆̆ıyla toplanmıştır. Elde edilen veriler içerik analizi aracılığlyla analiz edilmiştir. Araştırmanın verileri beş tema altında incelenmiştir. Araştırma sonucunda; katılımclların öğrenme/öğretme ortamı ve disiplin, zaman yönetimi ve ders süresi, duyuşsal özellikler ile esneklik ve erişilebilirlik bakımından uzaktan eğitim sürecine ilişkin olumlu görüşlerinin olduğu belirlenmiştir. Bunun tersine, katılımclların uzaktan eğitim sürecinde öğrenci-öğretmen iletişimi, öğrenme/öğretmedeki yetersizlikler, öz düzenleme/zaman yetersizlikleri, geri dönüt eksikliği, teknolojik problemler ve duyuşsal yetersizlikler bakımından olumsuz görüşlerinin olduğu belirlenmiştir. tekrar olduğu için
\end{abstract}

\footnotetext{
* Alıntılama: Arık, S., Karakaya, F., Çimen, O. ve Yılmaz, M. (2021). Covid-19 pandemi sürecinde uygulanan uzaktan eğitim hakkında ortaöğretim öğrencilerinin görüşlerinin belirlenmesi. Gazi Üniversitesi Gazi Ë̆itim Fakültesi Dergisi, 41(2), 631-659.
} 
ikisinden biri değiştirilmeli Ayrıca araştırmada, katılımcıların uzaktan eğitim sürecinin etkin ve verimle gerçekleştirebilmesi için daha çok soru çözümü, detaylı anlatım, ders saati ve zaman ayarlaması ve hizmet içi eğitimlerin yapılmasına yönelik öneride bulundukları tespit edilmiştir.

Anahtar Sözcükler: COVID-19, Ortä̈ğretim öğrencileri, Uzaktan ĕgitim

\begin{abstract}
This study aims to determine the opinions of secondary school students about distance education implemented during the COVID-19 pandemic process. The participants of the study that was designed as a case study which is from qualitative research methods, consisted of 55 secondary school students studying in different provinces of Turkey. The data of the study were collected through the "semi-structured interview form" prepared by the researchers. The obtained data were analyzed through content analysis. The study data were analyzed under the five themes. As a result of the research, it was found that the participants had positive views about the distance education process in terms of learning/teaching environment and discipline, time management and course duration, affective characteristics, and flexibility and accessibility. On the contrary, it was also determined that the participants had negative views about student-teacher communication, inadequacies in learning/teaching, inadequacies in self-regulation/time, lack of feedback, technological problems, and affective inadequacies in the distance education process. In addition, in the study, it was determined that the participants offered more suggestions about problem solving, detailed narration, course hour and time arrangements and doing in-service training in order to realize the distance education process effectively and efficiently.
\end{abstract}

Keywords: COVID-19, Secondary school students, Distance education

\title{
GíRiş
}

2019 yılında Çin'in Wuhan kentinde Koronavirüs kaynaklı insanlarda hızla yayılım göstererek ölümlere neden bir hastalık ortaya çıkmıştır (Rasmussen ve diğerleri, 2020). Hastalık başlangıç aşamalarında yeni koronavirüs (2019-nCoV) olarak tanımlanmıştır (Wang, Wang, Chen ve Qin, 2020). Daha sonraki süreçte Dünya Sağlık Örgütü (DSÖ [WHO]) tarafından yeni koronavirüs pnömonisi “COVID-19” (koronavirüs hastalığ 2019) olarak adlandırılmıştır (WHO, 2020). Hastalığın etkilerini en aza indirebilmek amacıyla birçok önlem (restoranların kapatılması, maske kullanımı, iş yerlerinde kısmi zamanlı, evden çalışma vb.) uygulanmıştır (Karakaya, Adıgüzel, Üçüncü, Çimen ve Yılmaz, 2021). Öğrenciler arasında yayılımını engellemek için Dünya genelinde COVID-19 pandemi sürecinde eğitim-öğretim faaliyetlerine yönelik farklı önlemler ve 
uygulamaları hayata geçirilmiştir. UNESCO (2020) raporları incelendiğinde, pandemi sürecinde eğitim-öğretim faaliyetlerine yönelik ülkelerin kısmen açık, tamamen açık veya kapalı şeklinde kararlar aldıkları görülmektedir. Kısmen açık ülkelerde (Örneğin Türkiye) eğitim-öğretim faaliyetlerinin aksamaması için uzaktan eğitim sürecinin entegrasyonu hızla gerçekleştirilmiştir.

Uzaktan eğitim, örgün eğitimin gerçekleştirildiği ortamlarda farklı olarak kurumsal ve iletişim teknolojileri aracılığı ile gerçekleştirilen eğitim şeklidir (Moore ve Kearsley, 2012). Bir başka ifadeyle uzaktan eğitim, iletişim teknolojilerinden yararlanılarak öğrenci, öğretmen ve eğitim materyalleri arasında etkileşimin gerçekleştirildiği eğitim anlayışıdır (Özgöl, Sarikaya ve Öztürk, 2017). Türkiye'de 23 Mart 2020 tarihinde uzaktan eğitime geçiş kararında sonra Milli Eğitim Bakanlığı (MEB) tarafından oluşturulan ve Türkiye'nin resmi dijital eğitim platformu olarak hizmet veren Eğitim Bilişim Ağının (EBA) altyapısını güçlendirilerek sürecin sağlıklı ilerlemesi sağlanmıştır (Karakaya ve diğerleri, 2021). Milli Eğitim Bakanlığı ve Türkiye Radyo Televizyon Kurumu (TRT) arasında gerçekleşen iş birliği (Özer, 2020) sonucunda pilot okullar belirlenerek TRT EBA TV ve EBA platformu üzerinden canlı ders uygulamaları başlatılmıştır (Canpolat ve Yıldırım, 2021). Ayrıca süreç içerisinde gerek devlet okulları gerekse özel okullarda farklı teknolojik uygulamaların eğitime entegrasyonunun gerçekleştirildiği gözlemlenmiştir.

Konu ile ilgili alanyazın incelendiğinde, Covid-19 pandemi sürecinde gerçekleşen uzaktan eğitime yönelik farklı ulusal çalışmaların olduğu görülmektedir. Örneğin, Canpolat ve Yıldırım (2021) ortaokul öğretmenlerinin, Karakaya ve diğerleri (2021) ise biyoloji öğretmenlerinin Covid-19 Pandemi sürecindeki uzaktan eğitim hakkında görüşlerini incelemişlerdir. Yaman (2021) yaptığı araştırmada, Türkiye ile Covid19 pandemisinin ilk ortaya çıktığı Çin'de uzaktan eğitim süreçleri ve uygulamaları incelemiştir. Yavuz, Kayalı, Balat ve Karaman (2020), Covid-19 pandemi sürecinde yükseköğretim kurumlarının gerçekleştirdikleri uzaktan öğretim faaliyetlerini ve salgın sonrasına ilişkin uzaktan öğretime yönelik planlamalarını incelemişlerdir. Ayrıca alanyazında Covid-19 pandemi sürecince gerçekleşen uzaktan eğitime yönelik 
uluslararası çalışmalarında (Cicha, Rizun, Rutecka ve Strzelecki, 2021; Marek, Chew ve Wu, 2021; Toquero, 2020; Yamamoto ve Altun, 2020; Zhou, Wu, Zhou ve Li, 2020) olduğu belirlenmiş̧tir. Örneğin Cicha ve diğerleri (2021) tarafından yapılan araştırmada, yükseköğretim kurumlarında öğrenim gören birinci sınıf öğrencilerinin uzaktan eğitimden beklentileri belirlenmiştir. Marek ve diğerleri (2021), Covid-19 pandemi sürecinde fakültelerdeki dönüşümlere yönelik öğretmen deneyimlerini tespit etmişlerdir. Toquero (2020) çalışmasında, pandemi sürecinin eğitim sistemlerine etkisini azaltmak ve başarıya ulaşmak için yükseköğretime yönelik önerilerini paylaşmıştır.

Uzaktan eğitimde başarı için en önemli kriterler öğrencilerin beklentilerini anlayabilmek $(\mathrm{Cab} 1,2018)$ ve onlara geri bildirim verebilmektir (Richardson, Koehler, Besser, Caskurlu, Lim ve Mueller, 2015). Çünkü öğrenciyi merkeze alan ve öğretmenin rehber olduğu bir anlayışta, ögrencilerin farklı kişilik özellikleri dikkate alınarak onlara daha iyi bir öğrenme ortamı sağlamak önemlidir (Turan, Şahin ve Altın, 2018). Ortaöğretim kademesinde öğrenim gören öğrencilerin kişilik özellikleri (dışadönük, içedönük, algısal, yargısal vb.) düşünüldüğünde, uzaktan eğitim sürecindeki öğrenmeöğretme ortamlarının zenginleştirilmesi için görüşlerinin belirlenmesi gerekmektedir. Ancak alanyazındaki incelendiğinde; öğretmen, veli, yükseköğretim ve ortaokul düzeyinde öğrenim gören öğrencilere yönelik çalışmaların ağırlıklı olduğu anlaşılmaktadır. Araştırmanın amacı kapsamında, ortaöğretim öğrencilerinin Covid-19 pandemi sürecinde gerçekleştirilen uzaktan eğime yönelik görüşlerinin belirlenmesinin alanyazına katkı sağlayacağı düşünülmektedir.

\section{YÖNTEM}

\section{Araștırma Deseni}

$\mathrm{Bu}$ araştırmada, nitel araştırma desenlerinden durum çalışması kullanılmıştır. Durum çalışması, sınırlı bir sistem içerisinde gerçekleșen olayların derinlemesine incelenmesidir (Merriam, 2013). Ayrıca durum çalışmasının gerçekleştirildiği araştırmalarda insanların, problemlerin veya programların tüm ayrıntılarıla 
incelenmesi gerçekleştirilebilir (Hays, 2004). Bu araştırmada, COVID-19 pandemi sürecinde uygulanan uzaktan eğitim hakkında ortaöğretim öğrencilerinin görüşlerinin derinlemesine incelenmesi amacıyla durum çalışması kullanılmıştır.

\section{Katılımcılar}

Araştırmanın etik ve bilimsel olarak uygunluğu Yozgat Bozok Üniversitesi Etik Komisyonu tarafından 17.06.2020 tarihli toplantısında değerlendirilmiş ve uygun olduğu kararı verilmiştir (Karar No: 11/03). Ayrıca etik kurallar gereği katılımcılardan bilgilendirilmiş gönüllü olur beyanları alınmıştır.

Araştırmanın katılımcı grubu, Türkiye'nin farklı illerinde (Ankara, Bolu, Eskişehir, Kahramanmaraş, Kocaeli, Konya, Kütahya, Mardin, Mersin ve Zonguldak) öğrenim gören 55 ortaöğretim öğrencisinden oluşmaktadır. Araştırma kapsamında katılımcıların gönüllülük esasına dikkat edilmiştir.

Araştırmaya katılan ortaöğretim öğrencilerine ait demografik bilgiler Tablo 1'de verilmiştir.

Tablo 1. Katılımcıların Demografik Bilgileri

\begin{tabular}{llcc}
\hline Demografik bilgi & & $\mathrm{n}$ & $\%$ \\
\hline \multirow{2}{*}{ Cinsiyet } & Kadın & 34 & 61.80 \\
& Erkek & 21 & 38.20 \\
\hline \multirow{2}{*}{ Kurum } & Devlet okulu & 42 & 76.30 \\
& Özel okul & 13 & 23.70 \\
\hline \multirow{2}{*}{ Uzaktan eğitim deneyimi } & Evet & 9 & 16.30 \\
& Hayır & 46 & 83.70 \\
\hline \multirow{2}{*}{ Sinıf Düzeyi } & 9. Sınıf & 11 & 20.00 \\
& 10. Sinıf & 20 & 36.40 \\
& 11. Sinıf & 14 & 25.40 \\
& 12. Sinıf & 10 & 18.20 \\
\hline
\end{tabular}




\section{Verilerin Toplama Aracı}

Verilerin toplanmasında araştırmacılar tarafından hazırlanan yarı yapılandırılmış görüşme formu kullanılmıştır. Yarı yapılandırılmış görüşme formunun geçerliliği için üç biyoloji eğitimcisi, bir fen eğitimcisi ve bir bilişim ve teknoloji uzmanından görüş alınmıştır. Uzman görüşleri doğrultusunda iki bölümden oluşan yarı yapılandırılmış görüşme formu oluşturulmuştur. Formun ilk bölümde, demografik bilgilerinin belirlenmesine yönelik sorular yer almaktadır. İkinci bölümde ise araştırmanın amacı doğrultusunda hazırlanan yedi soru yer almaktadır. Verilerin toplanma sürecinde https://docs.google.com/forms sisteminden yararlanılmıştır. Online olarak hazırlanan görüşme formu katılımcılara e-posta ve sosyal medya aracılığıyla ulaştırılmıştır. Formun giriş bölümünde, katılımcılara çalışmanın amacı hakkında bilgi verilmiştir.

\section{Etik Kurallara Uygunluk}

$\mathrm{Bu}$ araştırmanın tüm aşamalarında (çalışmaya hazırlık, araştırma konusunun belirlenmesi, veri toplama araçlarının hazırlanması, katılımcıların belirlenmesi, verilerin toplanması ve analizi, araştırmanın bulgularının yorumlanması ve bilgilerin sunulması) “Yükseköğretim Kurumları Bilimsel Araştırma ve Yayın Etiği Yönergesi” kapsamında belirlenen bilimsel etik, ilke ve kurallara uyulmuştur. Ayrıca araştırmanın etik kurallara uygunluğunu belirlemek için Yozgat Bozok Üniversitesi Proje Koordinasyon Uygulama ve Araştırma Merkezi Müdürlüğü Etik Komisyonu'ndan etik kurul onay belgesi (EK-1) alınmıştır.

\section{Verilerin Analizi}

Araştırmaya katılan ortaöğretim öğrencilerinin cevap formları (S1, S2, S3...) şeklinde kodlanarak isimlendirilmiştir. Veriler, içerik analizi yapılarak değerlendirilmiştir. İçerik analizi, verilerin belli temalar altında sınıflandırılarak birbiriyle ilişkisi ortaya çıkartılmasını sağlar (Yıldırım ve Şimşek, 2018). Bu nedenle verilerin analizi tümevarımsal içerik analizi ile gerçekleştirilmiştir. Bazı katılımcıların sorulara vermiş oldukları cevaplar birden farklı alt temada sınıflandırılmıştır. Veriler iki farklı kodlayıcı tarafından önce okunmuş ve bütüncül bir anlayış oluşturulmaya çalışılmıştır. 
Kodlayıcılar arası tutarlık Miles ve Huberman (1994)'`n Güvenirlik=Görüş birliği/ Tüm görüşler formülü aracılığıyla hesaplanmıştır. Sonuçta kodlayıcılar arası tutarlık değeri $\% 92$ olarak belirlenmiştir. $\mathrm{Bu}$ değerin $\% 80$ üzerinde olması verilerin güvenirliği açısından yeterli olduğunu göstermektedir (Creswell, 2013).

\section{BULGULAR}

Katılımcıların COVID-19 pandemi sürecinde uygulanan uzaktan eğitim sürecine ilişkin görüşleri: "Uzaktan eğitim sürecine ilişkin görüşler", "uzaktan eğitim sürecinde öğretmen - öğrenci iletişimi”, “uzaktan eğitim sürecinde görev ve sorumlulukların değişimi”, "uzaktan eğitimin biyoloji derslerine uygunluğu”, "pandemi sonrasında uzaktan eğitimin devamına ilişkin görüşler" ve "uzaktan eğitim sürecine ilişkin öneriler” temaları altında incelenmiştir.

\section{Uzaktan Eğitim Sürecine İlişkin Görüşler}

Katılımcıların COVID-19 pandemi sürecinde uygulanan uzaktan eğitim sürecine ilişkin görüşleri yarı yapılandırılmış görüşme formunda yer alan: "Geleneksel yöntemle karşılaştırdığınızda uzaktan eğitimin olumlu yönleri nelerdir?”, “Geleneksel yöntemle karşılaştırdığınızda uzaktan eğitimin olumsuz yönleri nelerdir?” ve "Uzaktan eğitim sürecinde yaşadığınız problemler nelerdir?” açık uçlu soruları aracılığıyla belirlenmiştir. Katılımcılardan elde edilen veriler içerik analizi yöntemi aracılığı ile analiz edilmiş ve elde edilen bulgular Tablo 2'de sunulmuştur. 
Tablo 2. Katılımcıların Uzaktan Eğitim Sürecine İlişkin Görüşleri

\begin{tabular}{|c|c|c|c|}
\hline \multicolumn{4}{|c|}{ Tema: Uzaktan Eğitim Sürecine İlişkin Görüşler } \\
\hline Olumlu Alt Temalar & $\mathrm{f}$ & Olumsuz Alt Temalar & $\mathrm{f}$ \\
\hline $\begin{array}{l}\text { Olumlu (O).1. Öğrenme / öğretme } \\
\text { ortamı ve disiplin }\end{array}$ & 22 & $\begin{array}{l}\text { Olumsuz (Oz).1. Öğrenme ve } \\
\text { öğretmedeki yetersizlik }\end{array}$ & 31 \\
\hline O.2. Zaman yönetimi ve ders süresi & 13 & $\begin{array}{l}\text { Oz.2. Öz düzenleme ve zaman } \\
\text { yetersizlikleri }\end{array}$ & 21 \\
\hline $\begin{array}{l}\text { O.3. Esneklik ve erişilebilirlik } \\
\text { (tekrarlanabilir, tamamlayıcı, } \\
\text { devamlılı...) }\end{array}$ & 10 & Oz.3.Geri dönüt eksikliği & 18 \\
\hline O.4. Duyuşsal yeterlilikler & 6 & $\begin{array}{l}\text { Oz.4. Duyuşsal yetersizlikler / } \\
\text { olumsuz duyuşsal özellikler }\end{array}$ & 17 \\
\hline O.5. Öğrenme ve öğretme süreci & 5 & $\begin{array}{l}\text { Oz.5. Teknolojik problemler ve } \\
\text { yetersizlikler }\end{array}$ & 14 \\
\hline $\begin{array}{l}\text { O.6. Ders sırasında bireysel } \\
\text { ihtiyaçlarını giderme }\end{array}$ & 2 & $\begin{array}{l}\text { Oz.6. Öğrenme ortamı ve } \\
\text { disiplin problemleri }\end{array}$ & 11 \\
\hline O.7. Firsat eşitliği & 2 & $\begin{array}{l}\text { Oz.7. İletişim ve sosyalleşme } \\
\text { kaynaklı yetersizlikler }\end{array}$ & 7 \\
\hline O.8. Olumlu değil & 12 & Oz.8. Olumsuz değil & 5 \\
\hline
\end{tabular}

Tablo 2 incelendiğinde, 22 katılımcı uzaktan eğitim sürecini öğrenme /öğretme ortamı ve disiplin, 13 katılımcı zaman yönetimi ve ders süresi, on katılımcı esneklik ve erişilebilirlik, altı katılımcı duyuşsal yeterlikler, beş katılımcı öğrenme ve öğretme süreci, iki katılımcı fırsat eşitliği ve iki katılımcı ise ders sırasında bireysel ihtiyaçları giderme bakımından olumlu bulduğunu ifade etmiştir. Bunun aksine 31 katılımcı uzaktan eğitim sürecini öğrenme ve öğretmedeki yetersizlikler, 21 katılımcı öz düzenleme ve zaman yetersizlikleri, 18 katılımcı geri dönüt eksikliği ve 17 katılımcı ise duyuşsal yetersizlikler /olumsuz duyuşsal özellikler, 14 katılımcı teknolojik problemler ve yetersizlikler, 11 katılımcı öğrenme ortamı ve disiplin problemleri ve yedi katılımcı ise iletişim ve sosyalleşme kaynaklı yetersizlikler bakımından olumsuz bulduğunu ifade etmiştir. Katılımcıların uzaktan eğitim sürecine ilişkin olumlu ve olumsuz görüşlerinden bazıları aşağıda verilmiştir: 
S1 (Olumlu): “1) Daha rahat bir ortam. 2) Sinıf ortamındaki arkadaşlar gibi dikkat dă̆ıtan etkenler olmadan ĕgitim firsatı. 3) Zaman tasarrufu sağlanabilecek bir sistem."

S23 (Olumlu): “1) Evde kendi rahat ortamımda çalışma düzenimi oluşturabilmek ve okulun stres veren ortamindan uzak olabilmek. 2) Zorunluluk olarak görmeksizin kendim için oluşturduğum ortamda çalışarak özsaygımı geliştirmesi. 3) Geleneksel yöntemde kalabalık ortamda olmaktan kaynaklanan dikkat dağıtıcı unsurlardan uzak en yüksek odak seviyesinde dersi dinleyebilmek."

S29 (Olumlu): "Kaydedilebilir olması."

S49 (Olumlu): “1) Ulaşım sorunu yok, 2) Herkes aynı eğitimi alıyor, 3) Sabah çok erken kalmamiza gerek yok, 4) Yemek için fazladan para vermeye gerek yok, 5) Ders kaçırırsak tekrarı var, 6) Ev okuldan daha rahat."

S3 (Olumsuz): “1) Soruları soramıyoruz. 2) Her ne kadar ben dinlesem de çoğu öğrenci dinlemiyor. Yoklama olmadĭ̆ için. 3) Çok uzun olmadiğı için yüzeysel anlatıllyor. Detaylara girilmiyor."

S9 (Olumsuz): "Ders çallşamıyorum motivasyonum yok."

S15 (Olumsuz): “Insanlarla iletişim kurma alanın azallyor ve sadece tek problemin oluyor hayatta ders çalışmak. Oysa bence problemler insanı geliştirir."

S33 (Olumsuz): “Internetimiz yetmiyor."

\section{Uzaktan Eğitim Sürecinde Öğretmen - Öğrenci İletişimi}

Katılımcıların uzaktan eğitim sürecinde öğretmenleriyle olan iletişimlerinin nasıl değiştiği: "Uzaktan eğitim sürecinin öğretmeninizle olan iletişiminizi nasıl değiştirdiğini düşünüyorsunuz? Nedenleriyle kısaca açıklayınız.” açık uçlu sorusu aracılığıyla belirlenmiştir. Katılımcılardan elde edilen bulgular Tablo 3 'te sunulmuştur. 
Tablo 3. Katılımcıların Uzaktan Eğitim Sürecinde Öğretmen - Öğrenci İletişimine İlișkin Görüșleri

\begin{tabular}{ll}
\hline Tema: Uzaktan Eğitim Sürecinde Öğretmen - Öğrenci İletişimi & \\
\hline Alt Temalar & $\mathrm{f}(\%)$ \\
\hline İletişim (İ).1. Olumsuz etki / Azalma & $22(40,00)$ \\
İ.2. Değişmedi & $21(38,18)$ \\
İ.3. Olumlu etki / Artma & $9(16,36)$ \\
İ.4. Diğer & $3(5,45)$ \\
\hline
\end{tabular}

Tablo 3 incelendiğinde, katılımcıların \%40’1 uzaktan eğitim sürecinde öğretmenleriyle iletişimlerinin olumsuz etkilendiği ve azaldığını, katılımcıların $\% 38,18$ 'i ise öğretmenleriyle iletişimlerinin değişmediğini ifade etmiş̧tir. Katılımcıların \%16,36's1 sürecinde öğretmenleriyle iletişimlerinin arttığını ve daha verimli hale geldiğini ifade etmişlerdir. Katılımcıların \%5,45'i ise bu konuda bilgisi olmadığını, bir katılımcı öğretmenini özlediğini, bir katılımcı ise sosyal ağlar aracılığıyla iletişim kurduğunu belirtmiştir. Katılımcıların uzaktan eğitim sürecinde öğretmen - öğrenci iletişimine ilişkin örnek görüşleri aşağıda verilmiştir:

S6 (Olumlu etki / Artma): "Bu süreçte bize çok yardımcı oluyorlar tüm sorularımızı çözüyorlar."

S50 (Olumlu etki / Artma): "Günün her saati onlara ulaşabilir olduk. Eksikliklerimizi gidermek için ellerinden gelen her şeyi yapıyorlar."

S10 - S11 - S12 - S13 (Değişmedi): "Değiştirmedi."

S27 (Değişmedi): "Değişmedi."

S34 (Değişmedi): "Değişmedi."

S44 (Değişmedi): "Değişmedi."

S28 (Olumsuz etki / Azalma): "Olumsuz yönde değiștirdi çünkü ögrretmenlerimiz bizim derste anlayıp anlamadı̆̆ımı sürekli kontrol ederdi, şimdiyse anlamadı̆̆ımı zaman soruyu o anda soramıyoruz."

S31 (Olumsuz etki / Azalma): “Birbirimizi görmediğimiz için öğretmenimin bazı şeyleri anlamadığımda yüz yüze eğitimde fark edip tekrar edebileceği şeyleri özellikle üzerlerinden zaman geçince sorma sıkıntısı yaşıyorum." 


\section{Uzaktan Eğitim Sürecinde Görev ve Sorumlulukların Değişimi}

Katılımcıların uzaktan eğitim sürecinde görev ve sorumluluklarının nasıl değiştiği: “Geleneksel yöntemle karşılaştırdığınızda uzaktan eğitim sürecinde size düşen görev ve sorumluluklar nasıl değişti? Kısaca açıklayınız.” açık uçlu sorusu aracılığıyla belirlenmiştir. Katılımcılardan elde edilen bulgular Tablo 4’te sunulmuştur.

Tablo 4. Katılımcıların Uzaktan Eğitim Sürecinde Görev ve Sorumluluklarının Değişimine İlişkin Görüşleri

\begin{tabular}{ll}
\hline Tema: Uzaktan Eğitim Sürecinde Görev ve Sorumlulukların Değişimi & \\
\hline Alt Temalar & $\mathrm{f}(\%)$ \\
\hline Görev (G) \& Sorumluluk (S).1. Artma / Daha çok çalışma & $29(52,73)$ \\
G\&S.2. Değişmedi & $13(23,64)$ \\
G\&S.3. Azalma / Rahatlama & $9(16,36)$ \\
G\&S.4. Diğer & $4(7,27)$ \\
\hline
\end{tabular}

Tablo 4 incelendiğinde, katılımcıların \%52,73’ünün uzaktan eğitim sürecinde görev ve sorumluluklarının arttığını ifade ettikleri dikkat çekmektedir. Katılımcıların \%23,64’ü görev ve sorumluluklarının değişmediğini ifade ederken, katılımcıların \%16,36'sı ise uzaktan eğitim sürecinde görev ve sorumluluklarının azaldığını ve rahatladıklarını ifade etmiştir. Ayrıca katılımcıların \%7,27'si “görev ve sorumluluğunun derslerini takip etmek olduğunu", "görev ve sorumluluğunun olmadığını” ve "ev işleri ile ilgili görev ve sorumluluklarının olduğunu ve aile etkisi ile görev ve sorumluluklarının değiştiğini”" ifade ederek diğer ( $\mathrm{f}=4$ ) alt temasında görüş belirtmiştir. Katılımcıların uzaktan eğitim sürecinde görev ve sorumluluklarının değișimine ilişkin örnek görüşleri aşağıda verilmiştir:

S4 (Artma / Daha çok çalışma): “Her şeyi kendim planlamam gerekiyor mesela dersimin olduğu zamana göre kendimi ayarlarken şimdi o ders saati yok bir nevi."

S55 (Artma / Daha çok çalışma): "Fazlasıyla yük! Kendi kendime kaldım, bir yandan iyi kendini eğitiyorsun. Ders çalışmak gelmese bile üniversiteye hazırlandığım için kendimi ders çalışmaya zorluyorum. Nefsi kontrol etmeli insan."

S5 (Değişmedi): “Değişmedi.” 
S34 (Değişmedi): "Değişmedi."

S43 (Değişmedi): "Değişmedi."

S44 (Değişmedi): "Değişmedi."

S54 (Değişmedi): “Pek bir şey değişmedi. Hocalarım hala benzer şekilde beni ödevlendirmekte. Okula ayırdığım vakti artık ders çalışarak harcıyorum."

S32 (Azalma / Rahatlama): "Sorumlulukların azaldığını düşünüyorum."

S46 (Azalma / Rahatlama): “Bence bize düşen sorumluluklar azaldı sadece belli saatler gelip kendimize ait dersleri dinleyip derse katıllyoruz daha az aktif durumda hissediyorum."

\section{Uzaktan Eğitimin Biyoloji Derslerine Uygunluğu}

Katılımcıların uzaktan eğitimin biyoloji derslerine uygunluğu: "Uzaktan eğitimin biyoloji derslerine uygun olduğunu düşünüyor musunuz? Nedenleriyle açıklayınız.” açık uçlu sorusu aracılığıyla belirlenmiştir. Katılımcılardan elde edilen bulgular Tablo 5 'te sunulmuştur.

Tablo 5. Katılımcıların Uzaktan Eğitimin Biyoloji Dersine Uygunluğuna İlişkin Görüşleri

\begin{tabular}{|c|c|c|c|}
\hline \multicolumn{4}{|c|}{ Tema: Uzaktan Eğitimin Biyoloji Derslerine Uygunluğu } \\
\hline Alt Temalar & & & $\sum \mathrm{f}$ \\
\hline \multirow{2}{*}{$\begin{array}{l}\text { Uygunluk (U).1. Uygun } \\
\text { / evet }\end{array}$} & Açıklama yapılmamış & 14 & \multirow{2}{*}{16} \\
\hline & Dersin doğası (sözel ağırlıklı olması) & 2 & \\
\hline \multirow{3}{*}{$\begin{array}{l}\text { U.2. Kısmen uygun (tek } \\
\text { başına yetersiz) }\end{array}$} & Konu özelliği & 1 & \multirow{3}{*}{4} \\
\hline & Dersin doğası (sözel ağırlıklı olması) & 1 & \\
\hline & Açıklama yapılmamış & 2 & \\
\hline \multirow{5}{*}{ U.3. Uygun değil / hayır } & Dersin doğası (uygulamalı deneysel olması) & 3 & \multirow{5}{*}{9} \\
\hline & $\begin{array}{l}\text { Dersin doğası (sayısal ve sözel ağırlıklı } \\
\text { olması) }\end{array}$ & 1 & \\
\hline & Dersin doğası (sayısal ağırlıklı olması) & 1 & \\
\hline & Dersin doğası (geri dönüt gerektirmesi) & 1 & \\
\hline & Açıklama yapılmamış & 3 & \\
\hline
\end{tabular}

Tablo 5 incelendiğinde, 16 katılımcı uzaktan eğitimin biyoloji dersine uygun olduğunu, dört katılımcı uzaktan eğitimin biyoloji dersine kısmen uygun olduğunu ve dokuz katılımcı ise uzaktan eğitimin biyoloji dersine uygun olmadığını belirtmiştir. Biyoloji dersinin uzaktan eğitime uygun olduğunu ifade eden katılımcıların ikisi biyoloji 
dersinin sözel ağırlıklı doğası nedeniyle uygun olduğunu ifade ederken; 14 katılımcı ise biyoloji derslerinin uygunluğunun nedenini açıklamamıştır. Biyoloji dersinin uzaktan eğitime kısmen uygun olduğunu ifade eden katılımcıların biri konuların özelliği, biri dersin sözel ağırlıklı doğası nedeniyle kısmen uygun olduğunu ifade etmiştir. İki katılımcı ise biyoloji derslerinin kısmen uygun olma nedenini açıklamamıştır. Biyoloji dersinin uzaktan eğitime kısmen uygun olmadığını ifade eden katılımcıların üçü biyoloji dersinin deneysel uygulama gerektirdiğini, biri sayısal ağırlığının olduğunu, biri sayısal ve sözel ağırlığının olduğunu, biri ise soru cevap gibi dönüt gerektirdiğini ifade etmiştir. Üç katılımcı ise biyoloji derslerinin uygun olmama nedenini açıklamamıştır. Katılımcıların uzaktan eğitimin biyoloji dersine uygunluğuna ilişkin örnek görüşleri aşağıda verilmiştir:

S27 (Uygun / evet): “Evet çünkü biyoloji sözel bir ders yani daha çok ezber olduğu için bir sıkıntı yaratmıyor."

S40 (Uygun / evet): “Uygun."

S21 (Kismen uygun (tek başına yetersiz)): "Klsmen uygun görüyorum."

S45 (Kısmen uygun (tek başına yetersiz)): “Biyoloji için 11. Sınıf düzeyinde müfredattaki son konular tehdit oluşturmuyor fakat diğer sınıflar için büyük problemler olabilir."

S2 (Uygunluk değil - hayır): “Uygun olduğunu düşünmüyorum. Deneylere dayall bir ders."

S37 (Uygunluk değil - hayır): “Uygun olduğunu düşünmüyorum.”

S51 (Uygunluk değil - hayır): "Hiçbir eğitimin yüz yüze eğitim kadar etkili olabileceğini düşünmüyorum ama uzaktan eğitimde de hocalarımız da gayet etkin bir şekilde anlattıkları için zorluk çekmedim çok."

\section{Pandemi Sonrasında Uzaktan Eğitimin Devamına İlişkin Görüşler}

Katılımcıların pandemi sonrasında uzaktan eğitimin devam etmesine ilişskin görüşleri: "Gelecekte uzaktan eğitim sürecinin devam etmesini ister misiniz? Nedenleriyle açıklayınız.” açık uçlu sorusu aracılığıyla belirlenmiştir. Katılımcılardan elde edilen bulgular Tablo 6' da sunulmuştur. 
Tablo 6. Katılımcıların Pandemi Dönemi Sonrasında Uzaktan Eğitimin Devamına İlişkin Görüşleri

\begin{tabular}{|c|c|c|c|}
\hline \multicolumn{4}{|c|}{ Tema: Pandemi Dönemi Sonrasında Uzaktan Eğitimin Devamına İlișkin Görüșler } \\
\hline Alt Temalar & & $\mathrm{f}$ & $\sum \mathrm{f}$ \\
\hline \multirow{6}{*}{ Devamlılık (D).1. İsteklilik / evet isterim } & $\begin{array}{l}\text { Olumlu duyuşsal } \\
\text { özellikler ve verimlilik }\end{array}$ & 4 & \multirow{6}{*}{14} \\
\hline & Zaman tasarrufu & 2 & \\
\hline & Gereklilik & 1 & \\
\hline & Destekleyicilik & 1 & \\
\hline & Deneyimleme & 1 & \\
\hline & Açıklama yapılmamış & 5 & \\
\hline \multirow{4}{*}{ D.2. Kısmen isterim / yüz yüze eğitim ile } & Tekrarlanabilirlik & 1 & \multirow{4}{*}{5} \\
\hline & İsteklilik / seçmeli & 1 & \\
\hline & Dersin doğası & 1 & \\
\hline & Açıklama yapılmamış & 2 & \\
\hline \multirow{8}{*}{ D.3. İsteksizlik / hayır istemem } & Dersin doğası & 6 & \multirow{8}{*}{29} \\
\hline & $\begin{array}{l}\text { Öğrenme ve öğretme } \\
\text { ortamı }\end{array}$ & 3 & \\
\hline & Olumsuz duyuşsal özellik & 3 & \\
\hline & İletişim yetersizliği & 3 & \\
\hline & Öğretmen yetersizliği & 2 & \\
\hline & $\begin{array}{l}\text { Öğrenme ve öğretme } \\
\text { yetersizliği }\end{array}$ & 2 & \\
\hline & Ders süresi & 1 & \\
\hline & Açıklama yapılmamış & 10 & \\
\hline
\end{tabular}

Tablo 6 incelendiğinde, 29 katılımcı pandemi sonrasında uzaktan eğitimin devam etmesini istemediğini, 14 katılımcı pandemi sonrasında uzaktan eğitimin devam etmesini istedikleri ve beş katılımcı ise pandemi sonrasında uzaktan eğitimin yüz yüze eğitim ile kısmen devam etmesi gerektiğini ifade etmiştir. Katılımcıların pandemi sonrasında uzaktan eğitimin devam etmesine ilişkin örnek görüşleri aşağıda verilmiştir:

S7 - S43 (İsteklilik / evet isterim): "Evet."

S52 (İsteklilik / evet isterim): “Biyoloji anlamında uzaktan eğitim mantıklı diğer derslere kıyasla ve bunun gelecekte de devam etmesi bence çoğu ögrenci için yararlı olabilir."

S19 (Kısmen isterim / Yüz yüze eğitim ile): “Isterim fakat seçmeli olmall. Isteyen uzaktan ĕgitim alabilmeli. Kendi tercihim okul yönünden olurdu ama." 
S4 (Kısmen isterim / Yüz yüze eğitim ile): “Evet biyoloji dersine çalışmak için faydall oluyor. Uzaktan eğitim okul ile beraber devam edebilir. Kurs gibi tekrar amaçlı ama okulun yerini tutacağını düşünmüyorum."

S24 - S25 - S30 - S33 (İsteksizlik / hayır istemem): "Hayır."

\section{Uzaktan Eğitim Sürecine İliş̧kin Öneriler}

Katılımcıların uzaktan eğitim sürecine ilişkin önerileri: "Uzaktan eğitimin yararlı olması için önerileriniz nelerdir?” açık uçlu sorusu aracılığıyla belirlenmiştir. Katılımcılardan elde edilen bulgular Tablo 7'de sunulmuştur.

Tablo 7. Katılımcıların uzaktan eğitim sürecine ilişkin önerileri

\begin{tabular}{ll}
\hline Tema: Uzaktan Eğitimin Sürecine İlişkin Öneriler & $\mathrm{f}$ \\
\hline Alt Temalar & 13 \\
\hline Öneriler (Ö).1. Görsellik ve görsel medya kullanımı & 8 \\
Ö.2. Süreç iyi yönetiliyor / Başarılı & 7 \\
Ö.3. Daha çok soru çözümü & 6 \\
Ö.4. Öğrenme ve öğretme süreci / Daha detaylı anlatım & 5 \\
Ö.5. Ders saati ve zaman ayarlaması & 3 \\
Ö.6. Daha fazla teknoloji kullanımı & 2 \\
Ö.7. Uzaktan eğitim olmamalı / Yararsız & 2 \\
Ö.8. Uygulamalı & 1 \\
Ö.9. Eğitici hizmet içi eğitimi & 1 \\
Ö.10. Birden fazla eğitici içeriği & 9 \\
Ö.11. Önerim yok / bilmiyorum & 57 \\
\hline Toplam
\end{tabular}

Tablo 7 incelendiğinde, 13 katılımcı uzaktan eğitim sürecinin daha başarılı olması için görsellik ve görsel medya kullanımın arttırılmasını, yedi katılımcı daha çok soru çözümü yapılmasını, altı katılımcı derslerin daha detaylı anlatılmasını, beş katılımcı ders saati ile zaman ayarlanmasının yapılmasını, üç katılımı daha fazla teknoloji kullanımı yapılmasını, iki katılımcı uygulamalı olmasını, bir katılımcı eğitici hizmet içi eğitimi yapılmasını ve bir katılımcının ise birden fazla eğitici içeriğinin olmasını önerdiği belirlenmiştir. Katılımcıların uzaktan eğitim biyoloji dersine ilişkin örnek görüşleri aşağıda verilmiştir: 
S14 (Öneriler): "Daha zor örnekler çözebilir."

S17 (Öneriler): "Saat ayarlamaları daha iyi yapılmall."

S22 (Öneriler): "Slayt yerine sistemler konusunun örneğim iskelet figürü ile anlatılması, soru çözümünün artması."

S23 (Öneriler): “Akıllı tahtada sunular üzerinden değil işlenen konuların gerçek videolarıla konuların anlatılması ve konu anlatımlarının maket veya çizimler üzerinden yapılması olabilir."

S26 (Öneriler): "Daha detaylı anlatım."

S41 (Öneriler): "Daha fazla soru çözümü.”

S53 (Öneriler): “Görsel üzerinden anlatmak akılda kalıcılı̆̆ı artırıyor, daha çok teknolojiden faydalanmak iş görür."

\section{TARTIŞMA ve SONUÇ}

Araştırmada, ortaöğretim öğrencilerinin Covid-19 pandemi sürecinde gerçekleşen uzaktan eğitim (çevrimiçi eğitim) hakkında görüşlerinin belirlenmesi amaçlanmıştır. Bu amaç kapsamında öğrenciler süreci, uzaktan eğitim sürecine yönelik genel bakış açısı, uzaktan eğitim sürecinde öğretmen-öğrenci iletişimi, uzaktan eğitim sürecinde görev ve sorumluluklarındaki değişim, uzaktan eğitimin biyoloji derslerine uygunluğu, salgın sonrasında uzaktan eğitimin devamına ilişkin görüşler ve öneriler açısından değerlendirmişlerdir.

Araştırmada, öğrencilerin uzaktan eğitime yönelik genel görüşlerini incelenmiştir. Araştırma sonucunda, öğrencilerin uzaktan eğitim sürecine yönelik öğrenme/öğretme ortamı ve disiplin, zaman yönetimi ve ders süresi, esneklik ve erişilebilirlik bakımından olumlu görüşlerinin olduğu belirlenmiştir. Öğrenciler, eğitimin ev ortamının rahatlı̆̆ında yapılması, sabah erken uyanma zorluluğunun olmaması, sınıf ortamındaki disiplin sorunlarının olmaması, derslerin daha kısa sürmesi, evde yapılması dolayısıyla zaman kaybını en aza indirmesi, kaydedilebilir özelliği dolayısıyla tekrar izlenebilir olması, sürekliliği sağlaması ve ortamın stressiz olması gibi nedenlerle uzaktan eğitimin 
olumlu olduğunu ifade etmişlerdir. Uzaktan eğitim süreci, zaman tasarrufu, mekândan bağımsız olma ve derslerin tekrarına imkân sağlaması gibi nedenlerden dolayı yararlı olduğu bilinmektedir (Balaman ve Hanbay Tiryaki, 2021; Karakaya, Arık, Çimen ve Yılmaz, 2020; Özgöl ve diğerleri, 2017; Özdoğan ve Berkant, 2020). Ayrıca uzaktan eğitim öğrencilerin ders materyallerine kolay ulaşabilmelerine ve ders tekrarı yapabilmelerine olanak sunması açısından faydalı süreçtir (Cabı, 2018; Gregory ve Lodge, 2015). Karakaya ve diğerlerine (2020) göre, zaman yönetimi, teknoloji kullanımı ve eğitimin devamlılığı açısından COVID-19 pandemi sürecinde gerçekleşen uzaktan eğitimin yararlı olduğunu belirtmişlerdir. Genç, Engin ve Yardım (2020), zaman-para-emek açısından kazanç ve kaynaklara kolay erişim sağlaması nedenleriyle uzaktan eğitim uygulamalarına yönelik lisansüstü öğrencilerin olumlu görüşlerini tespit etmişlerdir. Araştırmada öğrenme/öğretmedeki yetersizlikler, öz düzenleme/zaman yetersizlikleri, geri dönüt eksikliği ve duyuşsal yetersizlikler bakımından uzaktan eğitime yönelik öğrencilerin olumsuz görüşleri tespit edilmiştir. Öğrenciler, derslere ilişkin geri dönüt alamadıklarını, derslerle ilgili planlama yapamadıklarını, derslere adapte ve motive olamadıklarını ifade etmişlerdir. Ayrıca öğrenciler, uzaktan eğitim sürecinde teknolojik konularda sorun yaşadıklarını belirtmişlerdir. Konu ile ilgili alanyazın incelendiğinde araştırmanın bulgularını destekleyen çalışmaların olduğu belirlenmiştir. Örneğin, Karakaya ve diğerleri (2021) yaptıkları araştırma sonucunda, öğretmenlerin COVID-19 pandemisine bağlı olarak gerçekleşen uzaktan eğitimle ilgili zayıf etkileşim, verimsizlik, teknolojik alt yapı ve öğretmen yeterliklerinin eksikliğine bağlı olarak olumsuz görüşlerinin olduğunu belirlemişlerdir. Balaman ve Hanbay Tiryaki (2021) yaptıkları araştırmada teknik alt yapı eksikliği, motivasyon eksikliği, duyguların ifade edilememesi ve geri bildirim alınamaması gibi nedenlerden dolayı uzaktan eğitimin dezavantajlı olduğu sonucuna ulaşmışlardır. Pandemi sürecince gerçekleşen eğitimlerin yetersizliği öğrencilerin akademik başarıları da olumsuz etkilemiştir (Sintema, 2020). Bu sonuçlara göre, COVID-19 salgın sürecinde gerçekleşen uzaktan eğitim (çevrimiçi eğitim) sürecinin ortaöğretim öğrencileri açısından olumlu ve olumsuz yönlerinin olduğu söylenebilir. 
Araştırmada, öğrencilerin uzaktan eğitim sürecinde öğretmenleriyle olan iletişimleri incelenmiştir. Araştırma sonucunda, uzaktan eğitim sürecinin öğrenci-öğretmen iletişimlerini olumlu ve olumsuz etkilendiği belirlenmiştir. Öğretmenleri ile bu süreçte iletişiminin arttığını ifade eden öğrenciler, iletişimin daha verimli olduğunu, günün her saatinde öğretmenlerine ulaşabildiklerini ve rahat bir şekilde soru sorabildiklerini belirtmişlerdir. İletişime yönelik farklı teknolojik uygulamaların pandemi sürecinde kullanımının artması öğrenci-öğrenci, öğrenci-öğretmen arasındaki iletişimi hızlandırdığı görülmüştür (Chang ve Satako, 2020). Ayrıca pandemi sürecinde öğretmenlerin iletişime açık olmaları, öğrencileri desteklemeleri ve hızla geri dönüt vermeye yönelik düşünceye sahip olmaları öğrenci-öğretmen arasındaki iletişimin artmasını sağlamıştır (Genç ve diğerleri, 2020). Ancak öğretmenleri ile iletişimlerinin azaldığını ifade eden öğrenciler ise uzaktan eğitim sürecinde geri dönüt alamadıkları ve öğretmenleri ile görüşemediklerini belirtmişlerdir. Konu ile ilgili alanyazın incelendiğinde araştırmanın bulgularını destekleyen sonuçların olduğu tespit edilmiştir. Karakaya ve diğerleri (2021), bireyler (veli, öğretmen, öğrenci) arasındaki iletişim eksikliğinin COVID-19 pandemi sürecinde yaşanılan önemli sorunlardan biri olduğunu ifade etmişlerdir. Bakioğlu ve Çevik (2020) yaptıkları araştırmada, e-öğrenme ortamlarına yönelik yetersizliklerden dolayı öğretmen-öğrenci arasındaki iletişim sürecinin zayıfladığı sonucuna ulaşmışlardır. Şeren, Tut ve Kesten (2020) tarafından yapılan araştırma sonucunda, uzaktan eğitim sürecinde öğrencilerin yeterince dönüt alamadıkları ve öğretmenleriyle iletişim sorunları yaşadıkları tespit edilmiştir. Luo, Zhang ve Qi (2017), örgün öğretimin öğrencilerin öğretim ortamına olan aitlik hislerini artırdığını ifade etmiştir. İşlemsel uzaklık algısını (transactional distance), farklı ortamlarda bulunana öğrenci ve öğretmen arasındaki iletişimi zayıflatarak psikolojik boşluğa neden olmaktadır (Moore ve Kearsley, 2012).

Araştırmada, uzaktan eğitim sürecinde öğrencilerin görev ve sorumluluklarının nasıl değiştiği incelenmiştir. Araştırma sonucunda, öğrencilerin uzaktan eğitim sürecinde görev ve sorumluluklarının arttığı, azaldığı ve değişmediğine yönelik görüşlerin olduğu belirlenmiş̧tir. Görev ve sorumluluklarının arttığını ifade eden öğrenciler, derslerde 
anlamadıkları konuları öğrenmek amacıyla daha çok çalışmaları gerektiğini, daha fazla tekrar yapmaları gerektiğini ifade etmişlerdir. Ayrıca öğrenciler uzaktan eğitim sürecinde ödev sayılarının ve ev işleriyle ilgili sorumluluklarının arttığını ifade etmişlerdir. Görev ve sorumluluklarının azaldığını belirten öğrenciler ise zaman probleminin azaldığını, ödev ve sınavların azaldığını ve daha rahat olduklarını ifade etmişlerdir. Öğrencilerin pandemi nedeniyle evlerinde kalmaları hem öğrencilere hem de ebeveynlerin sorumluluklarını arttırmıştır. Ebeveynler, yeni eğitsel roller üstlenmiş ve eğitimin kesintisiz devam etmesini sağlamaya çalışmışlardır (Bozkurt, 2020). Uzaktan eğitim süreci, öğrencilerin ödev yüklerini (Genç ve diğerleri, 2020) ve ders çalışmaya ayrılan zamanı arttırmıştır (Karakaya ve diğerleri, 2020). Bu sonuçlar araştırmanın bulgularını desteklemektedir.

Araştırmada, uzaktan eğitim sürecinin biyoloji dersine uygun olup olmadığına yönelik öğrenci görüşleri incelenmiştir. Araştırma sonucunda, uzaktan eğitim sürecinin biyoloji dersine uygunluğuna yönelik öğrencilerin farklı görüşlerinin olduğu belirlenmiştir. Öğrenciler, biyoloji dersinin sözel ağırlıklı bir ders düşüncesiyle uzaktan eğitim sürecinin uygun olduğunu belirtmişlerdir. Karakaya ve diğerleri (2020) tarafindan yapılan araştırmada, öğretmenler dersin doğası, kullanılan teknolojik uygulamalar ve alternatif ölçme değerlendirme yöntemlerinin uzaktan eğitim sürecinde kullanılabilmesi nedeniyle uzaktan eğitim sürecinin biyoloji dersine uygun olduğunu ifade etmişlerdir.farklı bir ifade kullanılmalı Ancak araştırmada farklı görüşte olan öğrenciler (uygun değil); biyoloji dersinin deneysel uygulama gerektirdiği, sayısal ağırlığının olduğu ve soru-cevap gibi dönüt gerektirdiği belirtmişlerdir. Ayrıca bazı öğrenciler de biyoloji dersinin sözel yapısı ve konularının zorluğu nedeniyle uzaktan eğitimle yüz yüze eğitimin birlikte yürütülmesi gerektiğine dikkat çekmişlerdir. Mattheis, Ingram, Jensen ve Jackson (2015), biyoloji gibi bilimsel süreç odaklı derslerde yapılacak uygulamaların (deneyler) öğretim sürecinde vazgeçilmez unsurlar olduğunu vurgulamışlardır. Tekrar olduğu için farklı ifade olmalı Uzaktan eğitim uygulamaları, teorik odaklı derslerle kolaylık sağlamasına rağmen uygulama odaklı derslerde zorluklar yaşanmasına neden olmuştur (Kahraman, 2020). 
Araştırmada, pandemi sonrasında uzaktan eğitimin devam etmesine yönelik öğrencilerin görüşleri ve önerileri incelenmiştir. Araştırma sonucunda, pandemi sonrasında uzaktan eğitimin devam etmesine yönelik öğrencilerin farklı görüşlerinin olduğu belirlemiştir. Öğrenciler; zaman tasarrufu, gereklilik ve deneyimleme gibi nedenlerden dolayı pandemi sonrası uzaktan eğitim devam etmesi gerektiğini belirtmiştir. Ayrıca araştırmada, uzaktan eğitimin yararlı hale gelmesi için görsel medyanın kullanılması, daha çok soru çözümü, ders saati ve zaman yönetimi gibi konularda iyileştirmelerin yapılması gerektiğine yönelik öğrencilerin önerileri belirlenmiştir. Öğrencilere firsat eşitliğinin sağlanması (Li, Zhou ve Fan, 2014), farklı öğrenci gruplarına eş zamanlı ve aynı nitelikte eğitimin verilmesi (Cabı, 2018) uzaktan eğitimin tercih nedenleri arasında gösterilmektedir. Yapılan araştırmalar uzaktan eğitim sürecinde faydalı olabilmesi için eğitim-öğretim faaliyetlerinin dikkatli planlanması ve bireysel farklılıklar dikkate alınması gerektiğini göstermiştir (Kaden, 2020; Özdoğan ve Berkant, 2020). Pandemi sonrasında hazırlanacak online platformlar, yasal düzenlemeler ve yönetmelikler, gelecekte benzer durumlara daha hızlı uyum sağlanıp önlem alınmasını sağlayacaktır (Basilaia ve Kvavadze, 2020). Ancak derslerin doğas1, öğrenme ve öğretme ortamı, olumsuz duyuşsal özellik, iletişim ve öğretmen yetersizliği gibi nedenlerden dolayı öğrencilerin pandemi sonrası uzaktan eğitim devam etmemesi gerektiğini ifade etmişlerdir. Ayrıca bazı öğrencilerin konuya yönelik kararsızlıklarının olduğu tespit edilmiştir. Yapılan araştırmalar, COVID-19 pandemi sürecinde uzaktan eğitimle öğrenim hayatlarına devam eden öğrencilerde yalnızlık hissinin oluştuğunu (Lee, Ward, Chang ve Downing, 2021), mutluluk düzeylerinin ve fiziksel aktivitelerinin azaldığını (Munasinghe ve diğerleri, 2020) göstermiştir. Öğretmenler, COVID-19 pandemi sürecinin depresyon, okula aidiyetin azalması, etkileşim yetersizliği, motivasyon kaybı ve dijital bağımlılığın oluşması gibi öğrencilerde sosyal ve psikolojik etkilerinin olduğunu düşünmektedir (Karakaya ve diğerleri, 2021).

Sonuç olarak, COVID-19 pandemi sürecinde gerçekleştirilen uzaktan eğitimin olumlu ve olumsuz yönlerinin olduğu ortaöğretim öğrenci görüşleriyle belirlenmiştir. Uzaktan eğitimde sürecin daha etkili ve verimli gerçekleştirilebilmesi için teknolojik alt yapı, 
duyuşsal eksiklikler, iletişim aksaklıkları gibi konularda iyileştirme çalışmaların yapılması gerektiği söylenebilir. 


\section{KAYNAKLAR}

Bakioğlu, B., \& Çevik, M. (2020). Science teachers' views on distance education in the COVID-19 pandemic process. Turkish Studies, 15(4), 109-129. doi: 10.7827/TurkishStudies.43502

Balaman, F., \& Hanbay Tiryaki, S. (2021). The Opinions of Teachers about Compulsory Distance Education due to Corona Virus (Covid-19). Journal of the Human and Social Science Researches, 10(1), 52-84. Retrieved from http://www.itobiad.com/tr/pub/issue/60435/769798

Basilaia, G., \& Kvavadze, D. (2020). Transition to Online Education in Schools during a SARS-CoV-2 Coronavirus (COVID-19) Pandemic in Georgia. Pedagogical Research, 5(4), em0060. doi: 10.29333/pr/7937

Bozkurt, A. (2020). Koronavirüs (Covid-19) pandemi süreci ve pandemi sonras1 dünyada eğitime yönelik değerlendirmeler: Yeni normal ve yeni eğitim paradigması. Açıkögretim Uygulamaları ve Araştırmaları Dergisi, 6(3), 112 142. https://dergipark.org.tr/en/pub/auad/issue/56247/773769 adresinden erişilmiştir.

Cab1, E. (2018). Teaching computer literacy via distance education: Experiences of the instructors. Başkent University Journal of Education, 5(1), 61-68. Retrieved from http://buje.baskent.edu.tr/index.php/buje/article/view/93

Canpolat, U., \& Yıldırım, Y. (2021). Examining the distance education experiences of secondary school teachers in the COVID-19 outbreak process. Açıöğretim Uygulamaları ve Araştırmaları Dergisi, 7(1), 74-109. https://dergipark.org.tr/tr/pub/auad/issue/60075/840233 adresinden erişilmiştir.

Chang, G.C., \& Satako, Y. (24 Mart 2020). How are countries addressing the Covid-19 challenges in education? A snapshot of policy measures. Retrieved from https://gemreportunesco.wordpress.com/2020/03/24/how-are-countriesaddressing-the-covid-19-challenges-in-education-a-snapshot-of-policymeasures/

Cicha, K., Rizun, M., Rutecka, P., \& Strzelecki, A. (2021). COVID-19 and higher education: First-year students' expectations toward distance learning. Sustainability, 13(4), 1889. doi: 10.3390/su13041889

Creswell, J. W. (2013). Nitel, nicel ve karma yöntem yaklaşımları araştırma deseni. (G. Haciömeroğlu, Çev.) Ankara: Eğiten Kitap.

Genç, S.Z., Engin, G., \& Yardım, T. (2020). Postgraduate students' views related to application of distance education during the COVID 19 pandemic. Atatürk Üniversitesi Kazım Karabekir Eğitim Fakültesi Dergisi, (41), 134-158. doi: 10.33418/ataunikkefd.782142 
Gregory, M. S. J., \& Lodge, J. M. (2015). Academic workload: the silent barrier to the implementation of technology-enhanced learning strategies in higher education. Distance Education, 36(2), 210-230. doi: 10.1080/01587919.2015.1055056

Hays P. A. (2004). Case study research. In K. deMarrais \& S. D. Lapan (Eds.) Foundations for research: Methods of inquiry in education and the social sciences (pp. 218- 234). LEA.

Kaden, U. (2020). COVID-19 school closure-related changes to the professional life of a k-12 teacher. Education Sciences, 10(6), 165. doi: 10.3390/educsci10060165

Kahraman, M. E. (2020). The effect of COVID-19 epidemic on applied courses and the implementation of these courses by distance education: Example of basic design course. Medeniyet Sanat Dergisi, 6(1), 44-56. doi: 10.46641/medeniyetsanat.741737

Karakaya, F., Adıgüzel, M., Üçüncü, G., Çimen, O., \& Yılmaz, M. (2021). Teachers' views towards the effects of COVID-19 pandemic in the education process in Turkey. Participatory Educational Research, 8(2), 17-30. doi: 10.17275/per.21.27.8.2

Karakaya, F., Arık, S., Çimen, O., \& Yılmaz, M . (2020). Investigation of the views of biology teachers on distance education during the COVID-19 pandemic . Journal of Education in Science Environment and Health, 6(4), 246-258. doi: 10.21891/jeseh.792984

Lee, S. J., Ward, K. P., Chang, O. D., \& Downing, K. M. (2021). Parenting activities and the transition to home-based education during the COVID-19 pandemic. Children and Youth Services Review, 122, 105585. doi: 10.1016/j.childyouth.2020.105585

Li, F., Zhou, M., \& Fan, B. (2014). Can distance education increase educational equality? Evidence from the expansion of Chinese higher education. Studies in Higher Education, 39(10), 1811-1822. doi: 10.1080/03075079.2013.806462

Luo, N., Zhang, M., \& Qi, D. (2017). Effects of different interactions on students' sense of community in e-learning environment. Computers \& Education, 115, 153160. doi: 10.1016/j.compedu.2017.08.006

Marek, M. W., Chew, C. S., \& Wu, W. C. V. (2021). Teacher experiences in converting classes to distance learning in the COVID-19 pandemic. International Journal of Distance Education Technologies (IJDET), 19(1), 40-60. doi: 10.4018/IJDET.20210101.oa3

Mattheis, A., Ingram, D., Jensen, M. S., \& Jackson, J. (2015). Examining high school anatomy and physiology teacher experience in a cadaver dissection laboratory and impacts on practice. International Journal of Science and Mathematics Education, 13(3), 535-559. doi: 10.1007/s10763-013-9507-8 
Merriam, S. (2013). Nitel araştırma: Desen ve uygulama için bir rehber. (Çev. Turan, S.) Ankara: Nobel.

Miles, M., \& Huberman, A. (1994). Qualitative data analysis. Thousand Oaks, CA: Sage Publications.

Moore, M. G., \& Kearsley, G. (2012). Distance education: A systems view of online learning (3rd ed.). Belmont, CA: Wadsworth Cengage Learning

Munasinghe, S., Sperandei, S., Freebairn, L., Conroy, E., Jani, H., Marjanovic, S., \& Page, A. (2020). The impact of physical distancing policies during the COVID19 pandemic on health and well-being among Australian adolescents. Journal of Adolescent Health, 67(5), 653-661. doi: 10.1016/j.jadohealth.2020.08.008

Özdoğan, A. Ç., \& Berkant, H. G. (2020). The examination of stakeholders' opinions on distance education during the COVID-19 epidemic. Milli Ĕgitim Dergisi, 49(1), 13-43. doi: 10.37669/milliegitim.788118

Özer, M. (2020). Educational policy actions by the ministry of national education in the times of COVID-19 pandemic in Turkey. Kastamonu Eğitim Dergisi, 28(3), Retrieved from https://dergipark.org.tr/tr/pub/kefdergi/issue/54020/722280

Özgöl, M., Sarikaya, İ., \& Öztürk, M. (2017). Students' and teaching staff’s assessments regarding distance education applications in formal education. Journal of Higher Education and Science, 7(2), 294-304. doi: 10.5961/jhes.2017.208

Rasmussen, S.A., Smulian, J.C., Lednicky, J.A., Wen, T.S., \& Jamieson, D.J. (2020). Coronavirus disease 2019 (COVID-19) and pregnancy: what obstetricians need to know. Am J Obstet Gynecol. doi: 10.1016/j.ajog.2020.02.017

Richardson, J.C., Koehler, A., Besser, E., Caskurlu, S. Lim, J., \& Mueller, C. (2015). Conceptualizing and investigating instructor presence in online learning environments. International Review of Research in Open and Distributed Learning, 16(3), 256-297. doi: 10.19173/irrodl.v16i3.2123

Sintema, E. J. (2020). Effect of COVID-19 on the performance of grade 12 students: implications for STEM education. Eurasia Journal of Mathematics, Science and Technology Education, 16(7), em1851. doi: 10.29333/ejmste/7893

Şeren, N., Tut, E., \& Kesten, A. (2020). Distance education in corona virus times: opinions of lecturer's primary education department. Turkish Studies Education, 15(6), 4507-4524. doi: 10.47423/TurkishStudies.46472

Toquero, C. M. (2020). Challenges and opportunities for higher education amid the COVID-19 Pandemic: The Philippine Context. Pedagogical Research, 5(4), em0063. doi: 10.29333/pr/7947

Turan, H., Şahin, İ., \& Altın, E. N. (2018). Evaluation of personality characteristics and spare time preferences of high school students (Kocaeli example). Electronic Turkish Studies, 13(19), 1807-1820. doi: 10.7827/TurkishStudies.13803 
UNESCO (2020a). School closures caused by Coronavirus (Covid-19). Retrieved from https://en.unesco.org/ covid19/educationresponse

Wang, Y., Wang, Y., Chen, Y., \& Qin, Q. (2020). Unique epidemiological and clinical features of the emerging 2019 novel coronavirus pneumonia (COVID-19) implicate special control measures. Journal of medical virology, 92(6), 568576. doi: 10.1002/jmv.25748

World Health Organization (WHO) (2020). WHO Director-General's Remarks at the Media Briefing on 2019-nCoV on 11 February 2020. Retrieved from https://www.who.int/dg/speeches/detail/who-director-general-s-remarks-at-themedia-briefing-on-2019-ncov-on-11-february-2020

Yamamoto, G.T., \& Altun, D. (2020). The Coronavirus and the rising of online education. Journal of University Research, 3(1), 25-34. Retrieved from: https://dergipark.org.tr/tr/pub/uad/issue/53721/702735

Yaman, B. (2021). Examining the distance education processes and practices in Turkey and China during Covid-19 pandemic. OPUS International Journal of Society Researches, 17(Pandemic Special Issue), 1-1. Retrieved from https://dergipark.org.tr/en/pub/opus/issue/60563/857131

Yavuz, M., Kayalı, B., Balat, Ş., \& Karaman, S. (2020). Review of distance learning applications in the universities in the Covid-19 period. Milli Eğitim Dergisi, 49(1), 129-154. doi: 10.37669/milliegitim.784822

Yıldırım, A. \& Şimşek, H. (2018). Sosyal bilimlerde nitel araştırma yöntemleri (11. Bask1). Ankara: Seçkin.

Zhou, L., Wu, S., Zhou, M., \& Li, F. (2020). 'School's out, but class' on', the largest online education in the world today: Taking China's practical exploration during the COVID-19 epidemic prevention and control as an example. Best Evid Chin Edu 2020, 4(2), 501-519. doi: 10.15354/bece.20.ar023

\section{ORCID}

Selçuk ARIK (ID) https://orcid.org/0000-0003-4496-8104

Ferhat KARAKAYA iD https://orcid.org/0000-0001-5448-2226

Osman ÇİMEN iD https://orcid.org/0000-0001-8030-9996

Mehmet YILMAZ iD https://orcid.org/0000-0001-6700-6579 


\section{SUMMARY}

\section{Introduction}

In 2019, a disease caused by Coronavirus emerged in Wuhan, China, and caused the deaths of people by spreading rapidly (Rasmussen, et al., 2020). In order to minimize the effects of the disease, a lot of measures (closing restaurants, using masks, working part-time at workplaces, etc.) have been taken (Karakaya, et al., 2021). In order to prevent the spread of the disease among students, different measures have been taken for educational activities worldwide during the COVID-19 pandemic process. When the UNESCO (2020) reports are examined, it is seen that during the pandemic process, countries adopt decisions about educational activities as partial closure, full closure, or fully open. In partial-closure-in-effect-countries (such as Turkey), the integration of the distance education process was realized quickly in order to avoid disruption of educational activities.

Distance education is a form of education that is conducted through institutional and communication technologies, unlike in formal education settings (Moore \& Kearsley, 2012). The most important criteria for success in distance education are to understand the expectations of students (Cabl, 2018) and to give them feedback (Richardson, et al., 2015). When the personality characteristics (extrovert, introvert, perceptual, judgmental, etc.) of the students studying at the secondary education level are considered, their opinions should be determined in order to enrich their learning-teaching environments in the distance education process. However, when the literature is examined; It is seen that studies are mostly conducted with teachers, parents, students studying at higher education and secondary school levels. Within the scope of the purpose of the research, determining the opinions of secondary school students about distance education during the Covid-19 pandemic process is thought to contribute to the literature.

\section{Method}

The participants of the study that was designed as a case study which is from qualitative research methods, consisted of 55 secondary school students studying in different provinces of Turkey. The study data were collected through the "semi-structured interview form" prepared by the researchers. The obtained data were analyzed through content analysis. The study data were analyzed under the five themes.

\section{Findings}

As a result of the study, it was found that the participants had positive and negative opinions on the distance education process in terms of learning/teaching environment and discipline, course period, affective characteristics, and feedback. It was also determined that the participants had positive and negative opinions about student-teacher communication in the distance education process, the appropriateness of distance education to biology course, and the change of duties and responsibilities in the distance education process. In addition, it was determined that the participants offered more suggestions about problem-solving, detailed narration, course hour/time arrangement, and doing in-service training in order for the distance education process effectively and efficiently to be realized. 


\section{Discussion and Conclusion}

The distance education process is known to be useful for reasons such as saving time, being independent of the place, and allowing the repetition of the courses (Balaman \& Hanbay Tiryaki, 2021; Karakaya et al., 2020; Özgöl et al., 2017; Özdoğan \& Berkant, 2020). In addition, distance education is a useful process in terms of allowing students to easily access course materials and repeat courses (Cabl, 2018; Gregory \& Lodge, 2015). It has been observed that the increase in the use of different technological applications for communication during the pandemic process accelerates the communication between student-student, student-teacher (Chang \& Satako, 2020). Additionally, teachers who have been open to communication, have supported students, and have had the idea of giving feedback quickly caused an increase in communication between students and teachers (Genç et al., 2020). However, students who stated that their communication with their teachers decreased, indicated that they could not receive feedback and meet with their teachers during the distance education process. Karakaya et al. (2021) stated that the lack of communication between individuals (parents, teachers, students) is one of the important problems experienced during the COVID-19 pandemic process. 


\section{EK-1}

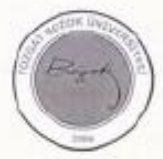

T.C

YOZGAT BOZOK ONIVERSITESI REKTORLÜGO

Proje Koordinasyon Uygulama ve Arașarma Merkezi Müdurluğì

Sayı : 95799348-050.01:04-E. 13500

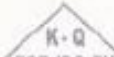

TSE.1SO-EN

9000

Konu : Etik Komisyonu 11. Toplants Kararlan

YOZGAT BOZOK ONNIVERSITESI RFKTÖRLOGONE Engelli Öğrenci Birimi

Üniversitemiz Etik Komisyonu'nun 17.06.2020 tarih ve 11 sayilı toplantısında almıs oldug̃u kararla, Oegr. Gür. Ferhat KARAKAYA tarafindan sunulan "COVID-19 Pandemi Sürecinde Uygulanan Uzaktan

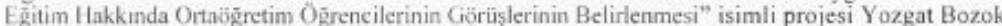
Üniversitesi Etik Komisyonu Yőnergesi kapsamında değerlendirilerek uygun görülmüș olup, ilgil yürütücüye teblig edilmesini arz ederim.

\section{e-imzalidur}

Doç. Dr. Irfan KOCA

Proje Koordinasyon Uygulama ve Arașturma Merkezi Müdürù

Ek: Öğr. Gör. Ferhat KARAKAYA Deǧerlendime Formu

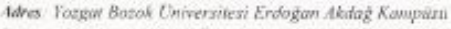

Bulgr icior RABA CURA

Elederowik

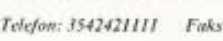

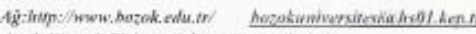

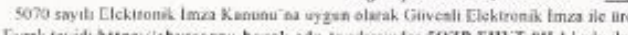

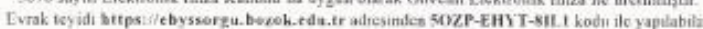




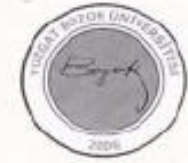

T.C.

YOZGAT BOZOK ON NIVERSITESI

ETIK KOMISYONE

BASVURU DEGERLENDIRME FORMU

\begin{tabular}{|c|c|c|c|}
\hline \multirow{5}{*}{ 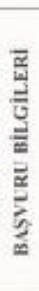 } & ARASTIRMANINADI & \multicolumn{2}{|c|}{ 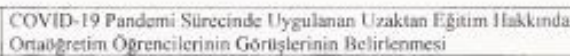 } \\
\hline & ARASTIRMANIN TORÖ & \multicolumn{2}{|c|}{ 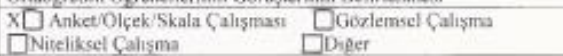 } \\
\hline & $\begin{array}{l}\text { GELEN EVRAK SAYISI ve } \\
\text { TARIHI }\end{array}$ & \multicolumn{2}{|l|}{$67615632-619-$ F. $_{12137} \quad 03.06 .2020$} \\
\hline & $\begin{array}{l}\text { YOROTOCODANISMAN } \\
\text { (Uavan, Ad-Seyad. Kurum. } \\
\text { Bölëm) }\end{array}$ & \multicolumn{2}{|l|}{$\begin{array}{l}\text { Ojg. Gïr. I crhas KARAKAYA } \\
\text { Yozgas Bazok Oniversitesi Engelli Ogrenci Birim }\end{array}$} \\
\hline & $\begin{array}{c}\text { ARASTIRMACILAR } \\
\text { (Uavas, Ad-Seyad, Kurom, } \\
\text { Bỏlüm) }\end{array}$ & \multicolumn{2}{|l|}{$\begin{array}{l}\text { Dr. Ogr. Oyesi Selçuk ARIK } \\
\text { Tokat Gariosmanpasa Universitesi }\end{array}$} \\
\hline & $\begin{array}{l}\text { ARASTIRMACILAR } \\
\text { (Uavas, Ad-Soyad, Kurum, } \\
\text { Bölüm) }\end{array}$ & \multicolumn{2}{|l|}{$\begin{array}{l}\text { Doç. Dr. Osman ÇIMIN } \\
\text { Gazi Tiniversitesi }\end{array}$} \\
\hline & $\begin{array}{c}\text { ARASTIRMACILAR } \\
\text { (Unvan. Ad-Soyad, Kurum, } \\
\text { Bëlüm) }\end{array}$ & \multicolumn{2}{|l|}{$\begin{array}{l}\text { Prof Dr. Mehmet YIL.MAZ } \\
\text { Gazi Cniversitesi }\end{array}$} \\
\hline \multirow{2}{*}{$\frac{5}{3}$} & $\begin{array}{c}\text { RAPORTOR } \\
\text { (Wavan, Ad-Seyad, Kurum, } \\
\text { Bosam, Telefon, E-Posta) }\end{array}$ & & Taritidimaxa \\
\hline & $\begin{array}{c}\text { DIS UZMAN } \\
\text { (Unvan, Ad-Seyad, Kurum, } \\
\text { Bülüm. Telefon, E-Posta) }\end{array}$ & & Tarihilimza \\
\hline
\end{tabular}

\begin{tabular}{|c|c|c|c|c|}
\hline \multirow{8}{*}{ 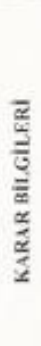 } & \multicolumn{2}{|c|}{ KARAR NO:11/93 } & \multicolumn{2}{|l|}{ TARIH: 17.06 .2020} \\
\hline & \multicolumn{4}{|c|}{ 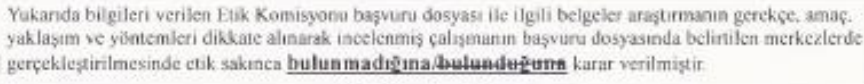 } \\
\hline & \multicolumn{4}{|c|}{ Dešerlendirme Sanucu } \\
\hline & $\bar{\nabla}$ & \multirow{2}{*}{\multicolumn{3}{|c|}{$\begin{array}{l}\text { Uygundur } \\
\text { Duzeltme gereklidir (Açskiayimiz) }\end{array}$}} \\
\hline & \multirow{2}{*}{$\square$} & & & \\
\hline & & \multicolumn{2}{|c|}{$\square$ Dischmeleri gormek istiyonuz } & ¿ Dozeltmelen gormemize gerck yok \\
\hline & D & \multicolumn{3}{|c|}{ Uygun degildir (Açıklayınaz) } \\
\hline & Açiklama & & & \\
\hline
\end{tabular}

CALIȘMA ESASI Yozquat Bozok Universitesi Ftik Komisyonu Youncrgesi

ETIK KOMISYONU ÜYELERI

\begin{tabular}{|c|c|}
\hline \multicolumn{2}{|c|}{ 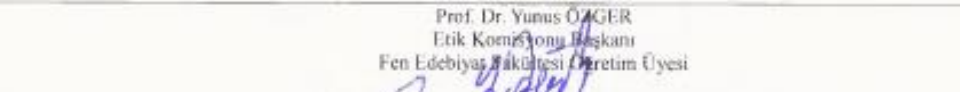 } \\
\hline $\begin{array}{l}\text { Doç. Dr Suat ERDI:M } \\
\text { llahiyat Fakaltesi Odgretim r }\end{array}$ & $\begin{array}{l}\text { Doc, Dr. Mchmet SAGLAM } \\
\text { Eging Fakatiesi Odretem Eyesi }\end{array}$ \\
\hline $\begin{array}{l}\text { Doc. Dr. Ibrahim DOGANG } \\
\text { lktisadi ve ladan Bilimier Fakiltesi Ogretim Oyesi }\end{array}$ & 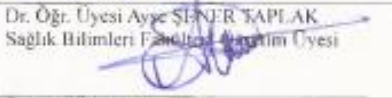 \\
\hline 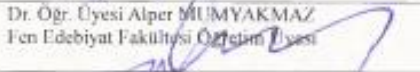 & $\begin{array}{l}\text { Oggr. Gör. Gutbal DOLU, } \\
\text { Sorgun Meslek Yaksatokulu Oegretim Elemam }\end{array}$ \\
\hline
\end{tabular}


